\title{
Abstract
}

\section{Employing those not expected to work: The stunning changes in the employment of single mothers and people with disabilities in the United States in the 1990s}

\author{
Richard V. Burkhauser and David C. Stapleton
}

This report compares the dramatic changes in the level of government benefits provided to single mothers and people with disabilities, especially in the 1990s. While welfare reforms and economic growth during the 1990s led to a dramatic increase in the employment of single women with children, the employment rate of individuals with disabilities dramatically declined, and continued to decline, in spite of peak periods of economic growth over the business cycle.

Published in: In Bernd Marin, Christopher Prinz and Monika Queisser (Eds.) Transforming Disability welfare Policies: Toward Work and Equal Opportunity. Burlington, VT: Ashgate Publishing Co. (2004), Pages: 321-332. For full text see publisher's website: http://www.ashgate.com/ 